STUDENT CORPORATE BRAND IDENTIFICATION: AN EXPLORATORY CASE STUDY This is a preprint (version of a paper accepted in its definitive form by Corporate Communications: An International Journal (C) Emerald Group Publishing Ltd, http://www.emeraldinsight.com and has been posted by permission of Emerald Group Publishing Ltd for personal use, not for redistribution.. The article will be published in Corporate Communications: An International Journal, Decision, Vol. 12, No.4. pp. 356-375. The definitive version of the paper can be accessed from:

http://www.emeraldinsight.com/Insight/viewContentItem.do;jsessionid=26E3576FCF20B033E89352DC99DC7A72?contentTyp $\mathrm{e}=$ Article $\&$ contentId $=1630601$

\title{
Student corporate brand identification: An exploratory case study
}

Professor John M.T. Balmer

Professor of Corporate Brand/Identity Management

Bradford School of Management

Bradford

UK

and

Dr. Mei-Na Liao

Lecturer in Marketing

Bradford School of Management

Bradford

UK 


\title{
STUDENT CORPORATE BRAND IDENTIFICATION: AN EXPLORATORY CASE STUDY
}

\begin{abstract}
Purpose: We investigate student corporate brand identification towards three corporate brands: a UK University, a leading UK business school and its overseas collaborative partner institute in Asia.

Methodology: A theory-building case study within the phenomenological/ qualitative research tradition
\end{abstract}

Findings: The strength of student identification to a corporate brand is predicated on awareness, knowledge and experience of a brand. The data revealed three types of corporate brand identification. This reflects different types of student relationships within the three institutions examined. We categorise these as follows: brand member (a contractual/legal relationship with a corporate brand); brand supporter (a trusting corporate brand relationship) and brand owner (an emotional ownership/relationship with the corporate brand). In explaining the above we view the above states in terms of a corporate brand identification management hierarchy which we categorise as legalisation, realisation and, finally, (brand) actualisation. Senior managers should strive for brand actualisation.

Research Limitations: The insights from a single, exploratory, case study might not be generalisable.

Practical Implications: We conceptualise that a bureaucratic/product management approach is more likely to result in low brand identification (legalisation); that a diplomatic/communications management approach is more likely to result in moderate brand identification (realisation) and finally, that a custodial/brand values and promise management approach is more likely to result in high brand identification (brand actualisation). These categorisations can have a utility in ascertaining the effectiveness of corporate brand management.

Originality/value of paper: Examines multiple student identification (towards a University, Business School and a non degree-awarding Overseas Institute).

Key Words: Business Schools, Corporate Branding, Corporate Brand Identification, Franchising, Higher Education, Universities. 


\section{Introduction}

Aesop's fable of the dispute between the North Wind and the Sun as to which was the strongest provides a salutary reminder that soft power can match, as well as surpass, hard power. You may remember that it was the sun's heat that caused the traveller to remove his coat rather than the brute force of the wind's power. There are lessons here for contemporary organisations which might fail to recognise the strength and strategic importance of their corporate brand and the importance of customer, employee and stakeholder (corporate brand) identification. This is especially the case in Higher Education (HE) where issues of identification with a corporate brand/identity appear to be of high saliency to students. As the recent student riot at Shengda Management College in the People's Republic of China demonstrates, brand identification can be a highly inflammatory issue. When the college decided that the word "Shengda" would appear on their degree parchments from Zhengzhou University students felt that this drew unwanted attention to the fact that their degree was not quite "the real thing" (The Economist 2006).

It is sometimes forgotten that the award of a degree accords a student lifelong membership of a University and can give an individual an important sense of identification with the corporate brand and as a means of defining the self even well beyond graduation. For instance graduates of 'Oxbridge' in the UK, the 'Ivy league' in the USA and the Grande Ecole in France have strong life-long affiliation to their university beyond their University years with graduates from such institutions forming a cultural elite and occupy positions of prominence within government and business: graduates of the Ecole Nationale d'Administration (ENA) in Paris exemplify this perspective.

Our examination of the relationship between student and institution through the lens of corporate brand identity has led us to the conclusion that students 
are not so much customers but are, moreover, life-long organisational members of a corporate brand community. As such, the compact between University/Business School and student is a very special one. We believe our examination of student identification with a University/Business School and Overseas Partner Institute is one of the first empirical studies of its kind.

Recently an identity based perspective has informed our comprehension of corporate brands (Balmer 2001, 2005, Kapferer, 2002) along with that of corporate marketing (Balmer and Greyser 2006). Moreover, issues of corporate identification from employee (Dutton, et al., 1994; Dutton, et al., 2002) and consumer (Bhattacharya and Sen, 2003) perspectives have emerged as significant strands of thought within both the marketing and organisational behaviour literatures on identity. Not surprisingly, stakeholder corporate identification has been recognised as an important facet of the nascent area of corporate marketing by scholars (Balmer and Greyser 2006). However, it appears that little in the way of empirical research has taken place in relation to customer identification with corporate brands per se, especially in a higher education context. Of note, however, is Mael and Ashforth's (1992) study broader on alumni identification.

From our scrutiny of the Higher Education sector, it would seem that senior managers are beginning to examine their institutions through a corporate branding lens. However, the degree of importance attached to corporate branding varies between institutions as it does between countries. For instance, corporate brand building appears to be higher up the food chain among North American Universities - especially Business Schools - in contrast to many (but by no means all) of their European counterparts where scepticism often abounds vis a vis the utility of corporate brand management. It would appear that such ambivalence also manifests itself towards other 
dimensions of corporate marketing ${ }^{1}$ (Balmer, 1998; 2006; Balmer and Greyser 2003) such as corporate communications (Cornilissen et al 2001, Goodman 2001, Karaosmanoglu and Melewar 2006; Varey and White 2000; Yamauchi 2001; Van Riel 1005).

Taking a broader perspective, it has been argued that corporate level concepts (corporate brands, corporate identity, corporate communications, corporate reputation etc) should not be seen, or managed, in isolation of each other but, rather, should be viewed as part of a broader gestalt and organisational philosophy: that of corporate marketing (Balmer and Greyser 2006). Exhibit one replicates Balmer's (2006) corporate marketing mix and shows the prominence of corporate branding and corporate communications within a corporate marketing context. What does appear to be the case is that increased competition within the HE sector has resulted in Vice Chancellors of leading Universities and Deans of top Business Schools acknowledging the strategic importance of having strong corporate brands. As the Dean of RSM Erasmus University Rotterdam, Professor van Dissel, noted:

"Because of Bologna [the Bologna Accord], we realised we were operating in a market that would move from product branding to institutional branding... We have to brand our institution, which is far more effective than branding the MBA"

(Financial Times, 2006, p. 8).

This shift towards a corporate brand management (and by inference increased importance to corporate communications and, taking a broader perspective, corporate marketing) has resulted, it seems to us, to a more student and stakeholder oriented approach within the HE sector. As such, stakeholder identification with HE brands is likely to be a corollary concern on the part of senior managers. 


\section{KINDLY TAKE IN EXHIBIT ONE HERE PLEASE}

Our research examines student identification at the level of the corporate brand and provides some preliminary insights into this somewhat underexplored area. We focus on undergraduates reading for business studies degrees at one UK University (including those undergraduates studying at an overseas collaborative partner institution). We investigate three different groups of students (a) students studying in UK home programme, (b) students studying in overseas collaborative programme and (c) students who started their degree in overseas collaborative programme and who have now transferred to the UK home programme. A distinctive feature of our study is that we examine student identification at three levels: with the degree awarding UK University; the UK service provider and, lastly, the overseas local provider.

\section{Corporate Brand Franchising in UK Universities}

Progressively, Universities 'export' their degree courses to overseas countries by entering into franchise partnerships with locally-based institutions. This, of course, mirrors the increased incidence and importance of franchising in the contemporary global environment (Hoy and Standworth 2002). The value of franchising activities in HE has grown exponentially during the last decade as higher education institutions, as well as governments, have increasingly recognised the enormous potential of overseas markets for UK Universities. Franchising arrangement are indicative of the increased importance of corporate branding within the British HE sector. Recently, it was estimated that the above activities are worth $£ 3.6$ billion to the UK economy (Universities $U K, 2006)$. Furthermore, Higher Education collaborative programme offer distinctive benefits to five, distinct, groupings namely, the UK and Overseas 
Governments; UK Universities; Overseas Partner Institutions and, finally, Students.

The British Government recognises the important economic and cultural influence of these programmes whilst overseas governments appreciate their significance in terms of knowledge transfer and moreover the economic benefits that flows from having a highly educated workforce. UK Universities derive financial benefits from income streams generated through franchising and (by working with local providers) affords such institutions a relatively easy means of entering overseas markets. Overseas partner institutions benefit from marshalling the 'corporate brand' power of established, and well-regarded, UK Universities. In addition they benefit from the generic industry-wide brand that encompasses the UK University sector. This accords them benefits in terms of corporate brand prestige, market differentiation and a widening of their service portfolio. Finally, for students, there are benefits in taking a degree from a respected UK University whilst studying locally in a culturally-familiar setting, where costs are lower. Such degree programmes often lead to enhanced employment opportunities (Fallshaw, 2003).

The management literature on the higher education sector has primarily focussed on problems associated with operational issues relating to internationalisation (Yu, 1996; Teichler, 1999; Dobson and Holtta, 2001, Altbach, 2004), the effectiveness of advertising and the use of promotional material (Gatfield, et al.,1999; Gray, et al., 2003), study relating to alumni use of affinity cards (Worthington and Horne's 1995), the competitive advantages and success factors of the marketing of universities (Mazzarol, 1998; Mazzarol and Soutar, 1999) and, more recently, issues of quality assurance and control within the HE sector (Lloyd and Wiser, 2006; Fallshaw, 2003). Again, we wish 
to reiterate that we were unable to find a study the examined student identification with a HE corporate brand.

For the main, we found that the general marketing literature conceives students, in conventional terms, as customers (see for example, Kotler and Fox, 1995, Siu and Wilson, 1998; Armstrong, 2003). However, it has been argued that student should be seen as partners (Ferris, 2002; 2003). We go further. For us, a student is not only a consumer/customer/client of a University but is a life long member/co-owner of the institution's corporate brand.

\section{Corporate Branding: Corporate Identity Perspectives}

In recent years, branding scholarship has gradually widened to encompass, products, services and corporations. Even arcane institutions such as the British Monarchy are now viewed through the lens of corporate branding (Balmer et al., 2006). Scholarly interest in corporate brand has burgeoned since the mid 1990's and an extensive literature now characterises the area (Aaker and Joachimsthaler, 2000; Aaker, 2004; Balmer, 1995; Balmer and Gray, 2003; de Chernatony, 2002; de Chernatony and Segal-Horn, 2003; Schultz and de Chernatony, 2002; Gylling et al 2006; Hatch and Schultz, 2001; Kapferer, 2002; Keller and Lehmann, 2005; Knox and Bickerton, 2003; Muzellec and Lambkin 2006; Uggla 2006). Although certain features of branding theory are broadly applicable across all three branding categories there are notable differences among them (MacDonald and de Chernatony, 1993). Within the literature (Balmer and Gray, 2003; de Chernatony, 2002; 2006; Hatch and Schultz, 2005) a consensus has emerged as to some of the distinctive differences between corporate brands and product brands. For example, the CEO is the corporate brand manager, and all personnel are seen to be corporate brand spokespersons. The distinction, however, between corporate and service 
brands is not always so clear and can lead to schisms between those who take a monolithic approach to branding theory in contrast to those who adopt a more bespoke view (Ambiola, 2006).

Just as an identity-based perspective has informed the general comprehension of product brands the same is true with regard to corporate brands (Balmer, 2001; 2005; Kapferer, 2002; de Chernatony, 2002). As such, our discussion of corporate brands, and the general understanding of them, has been informed by the literature on corporate identity and identification (viz: Abratt, 1989; Bhattacharya and Sen, 2003; Balmer, 1995; 2001;2003; Balmer and Wilkinson, 1991; Balmer and Greyser, 2002; Bick, et al., 2003; Bronn, et al., 2006; Brown, et al., 2006; Cardador and Pratt, 2006; Melewar, 2001; Melewar and Jenkins, 2002; Melewar, et al., 2003; Melewar and Karaosmanoglou, 2006; Simoes et al., 2005; Stuart, 1999; Van Riel and Balmer,1997.)

Within the marketing literature, three principle schools of thought tend to characterise research and scholarship on corporate identity and identification. Of course, it should be realised that broader perspectives on the area can be found within the literature (Balmer 1995; Cornilissen et al 2006; ( Melewar, XX2001;). These schools of thought are broadly analogous to the different ways in which corporate brands can be understood and researched. The three schools of thought are as follows: (a) Visual Corporate Brand Identification (b) Corporate Brand Identity (c) Customer and Stakeholder Corporate Brand Identification.

\section{(a) Visual Corporate Brand Identification.}

Just as corporate identity was originally conceptualised in terms of visual identification (Margulies, 1977; Napoles, 1988; Olins, 1978; Pilditch, 1971; Selame and Selame, 1975) the same is true of branding with the brand-mark 
having an important role as an identifying mark/mark of ownership (de Chernatony and McDonald, 1993; de Chernatony, 2006). Visual identification remains an important aspect of corporate branding/corporate identity scholarship (Abratt, 1989; Melewar, 2001; Schroeder, 2005; Stuart, 1999; Van den Bosh et al 2006; Van Riel and Balmer, 1997; Westcott Alessandri 2001). It also characterises some of the more recent work emanating from the US (Brown, et al., 2006). Broadly speaking, the above school emphasis the importance role of projecting a single image to a corporate brand community via symbolism/visual identity and has the objective of creating a stereotype and positive image of the brand among stakeholder groups.

\section{(b) Corporate Brand Identity}

Just as corporate identity scholarship (Balmer, 1995; Balmer, 2002; Balmer and Greyser, 2002; Simoes, et al., 2005; Melewar and Karaosmanoglu, 2006; Westcott Alessandri 2001) has, increasingly, focussed on the defining characteristics of an organisation (corporate identity) so have the defining characteristics of corporate brand been stressed in the literature. Whereas corporate identity scholarship emphasises the centrality of strategy, structure and culture of corporate identity (Balmer, 2001, 2002; Melewar and Jenkins, 2002; Bick, et al., 2003) the literature on corporate branding emphasises the importance of corporate values, coordinated corporate communications and consistency in corporate brand promise (Balmer, 2001; de Chernatony 2002, Hatch and Schultz, 2003; Kapferer, 2002; Urde 2003, Vallaster and de Chernatony 2006).

\section{(c) Customer and Stakeholder Corporate Brand Identification}

Customer and Stakeholder Identification, broadly speaking, relates to the degree to which an individual's, or groups, affinity with an organisation mirrors the distinctive characteristics of an organisation (Dutton, et al., 1994). 
It is not difficult to see how this perspective is applicable to corporate brands. For instance, it has been shown that employee identification towards an organisation is stronger where the organisation is associated with high quality attributes. Such association accords an individual or a group prestige (Dutton, et al., 1994; Dukerich, et al., 2002; Pratt, 1998). Marketing scholars such as Bhattacharya and Sen (2003) have drawn on this scholarship in order to examined customer-company identification. However, little work has been undertaken with regard to corporate brand identification per se.

One relevant, and recent, stream of research highlights the importance of brand communities (Cova and Pace, 2006; Shouten and Alexander, 2005; McAlexander, et al., 2002) and the related notion of brand tribes (Arnauld, et al., 2002; Solomon, 2003). For the main, the above research focuses around cult brands but little (if anything) appears to be related to corporate brands, especially those relating to Higher Education.

In reflecting of the above we believe that our research is distinctive in that it:

(a) focuses on corporate brand identification

(b) examines student identification within Higher Education both in $U K$ and Asian contexts

(c) examines student identification towards three HE institutions (a UK University; a UK Business and an Overseas Partner Educational Institute operating in Asia).

\section{Objectives and Methodology}

The research settings for our investigation were (i) a well-established UK Business School based at (ii) an established UK University sited in an English 
Cathedral City and (iii) a Collaborative Partner Institution operating in Asia (which delivers degree programmes from the University/Business School).

Our exploratory case study research investigates the nature of student identification among three, distinct, categories of undergraduate student reading for a business degree from a single, UK, University. It has an explicit internal/institutional foci in that we examine student identification towards a) the degree awarding University in the UK, b) its Business School and c) an overseas collaborative partner education institute in Asia.

A qualitative approach was assumed for this study since our objectives were to describe, decode, translate, and otherwise come to terms with the meaning, not the frequency, of certain more or less naturally occurring phenomena in the social world (Van Maanen, 1988). A theory building case study methodology was deemed appropriate since this approach is most appropriate when little is known about a phenomenon (student identification towards competing corporate brands) and where in consequence there can be little reliance on the literature (Gill and Johnson, 1991: p.119). In addition, case study research is a useful strategy for studying processes in organisations and for explanatory/exploratory investigations (Gummesson, 1991). The efficacy of case study research has been made by a number of prominent scholars (Stake, 1978; Yin 1984; Eisenhardt, 1989) as has the utility of relying on a single case study (Normann, 1970). A recent example of the above methodological approach in relation to branding can be found in the study by Vallaster and de Chernatony (2006).

Data collection was undertaken via focus group discussions with students both in the UK and Asia. As such, students voiced their responses to our questions relating to their type and strength of identification to the three corporate brands under scrutiny. An interview topic guide was used to frame 
focus group discussions. All interviews were recorded and transcribed and followed a three stage coding process that is common in qualitative research namely, open-coding/axial-coding/selective coding (Easterby-Smith, et al, 2002). Data was coded by hand rather than by using computer software. In terms of the triangulation of data this was achieved via the three sources of information that was generated during the focus group discussions, namely, (a) data given in direct response to a question, (b) data given in response to a pertinent question not given in the topic guide and (c) unsolicited-additionalinformation provided by one or more students. The process of analysis/synthesis was both iterative and corroborative in nature. Frequent and long meetings were held between both researchers which fostered a greater in-depth, and critical, understanding of the phenomenon under scrutiny. Following the general protocol of qualitative research, our collection, analysis and interpretation of data took place simultaneously (Gummesson, 2005).

\section{Findings}

Our research results provide two categories of findings. The first finding (a) revealed three types of student identification with the business school's corporate brand (brand membership, brand supporter and brand owner.) The second finding (b) suggested that when an overtly managerial perspective is adopted three approaches appear to characterise the management of corporate brand identification which we call legalisation, realisation and actualisation. As such legalisation is more likely to lead to students seeing themselves as brand members whereas realisation leads to students viewing themselves as brand supporters and actualisation leads to students regarding themselves as brand owners. 


\section{(a) Categories of Corporate Brand Identification}

The category of brand membership defined the purely contractual and legal relationship that undergraduates at the collaborative partner institution in Asia had with the British University. The category of brand supporter reflected the trusting corporate brand relationship that students (originally from the collaborative partner institution but now studying in the UK) had with the Business School. Finally, the category of brand 'owner' reflected the emotional ownership/relationship that UK undergraduates had with the Business School.

(b) Categories of Corporate Brand Management

In explaining the above we view this as a corporate brand identification management hierarchy which we label legalisation, realisation and, finally, (brand) actualisation (See Exhibit Two). Legalisation is where both corporate brand manifestations and student identification with the corporate brand are low and appears to characterise an institutional concern with financial, functional and legal concerns. Realisation is where both corporate brand manifestations and student identification with the corporate brand are moderate in degree and appears to characterise an institutional concern with the symbolic and the promotional management of corporate brands. Actualisation is where both corporate brand manifestations and student identification with the corporate brand are high and where undergraduates have a proprietorial/emotional relationship with the brand. Institutionally, there appears to be a concern with brand values and 'the corporate brand promise.' Senior managers should strive for brand actualisation.

The data suggests that the three categories of student identification cited above are not mutually exclusive. This is because, identification with a corporate brand is complex in nature. Although "Actualisation" might best 
describe a given situation there might still be elements of the brand relationship that can best be described as "Legalisation" (for instance, certain forms of corporate communication and behaviour which focus on contractual rather than on branding aspects). This aspect of our finding merits further exploration.

Exhibit Two illustrates our hierarchy of corporate brand identification.

\section{KINDLY TAKE IN EXHIBIT TWO HERE PLEASE}

Data from our study revealed that the strength of student identification with a corporate brand, as indicated in the corporate brand identification hierarchy, was found to be linked to the following facets:

(a) brand reputation and prestige

(Students were conscious of the reputation of reputation and prestige of higher educational brands: they frequently mentioned this point and often made reference to the ranking lists of business schools.)

(b) brand community

(Belonging to a distinct brand community was often cited to be of importance by students.)

(c) corporate ethos and identity

(The corporate ethos and the identity traits of a school were found to be of material importance to students.) 
(d) member and physical evidence

(Undergraduates were conscious of the academic quality of fellow students and found the academic standing and professionalism of MBA students to be inspiring.)

(e) brand differentiation

(Students often defined their identification with a HE brand by referring to other brands which they regarded to be of inferior quality and which they had weaker identification with.)

We found the corollary also to be true namely the absence of the above could result in unrequited identification (seeking identification with the University brand on the part of students in Asia) and non-identification (ignorance of the prestige associated with the business school brand: again from undergraduate students in Asia).

However, it would seem that the above is predicated on a student's awareness, knowledge and experience of a brand. For instance, whereas students studying in the UK had a strong and positive affinity with the business school brand (and a lower affinity to the University brand) undergraduates studying at the overseas partner institute only associate with the University brand. Exhibit Three illustrates our interpretation of the relationship between the strength of student identification and the strength of corporate brand manifestations.

\section{KINDLY TAKE IN EXHIBIT THREE HERE PLEASE.}

The following section outlines the nature of the findings in more detail relating to the three types of identification outlined above. 
Brand Member - undergraduates studying at the Asian Partner Institute (API)

The dominant type of identification at the above was with the group of students at the institute rather than the institute per se. At the institutional level, undergraduate's primary identification was, by default rather than by desire, with the collaborative partner institution. However, these students sought to have a strong identification with the University which they understood to be the most prestigious of the HE brands with which they had an association (rather than with the business school). However, incidents of brand manifestations were low or not existent (unlike the above). Their knowledge of the business school was even slighter and may, in several cases, be almost non-existent. In quasi-legal terms these students had a life-long relationship with the school (through the award for life of a degree qualification). This was not the case with the partner institution where membership is terminated upon graduation.

Unlike home undergraduates who, focussed on the brand reputation of the business school, these students focussed on the reputation of the University (and perhaps the generic brand reputation of UK Universities).

Brand Supporter - undergraduates from the API now studying in the United Kingdom

Overtime these students shifted their primary affiliation from the collaborative partner institution to the business school's corporate brand. This is interesting since there was an absence of association to the business school's corporate brand prior to their move to the UK. Also, they demonstrated a higher affinity with the Business School than with the University. This shift in identification is clearly explained in terms of knowledge, awareness and 
experience of the business school which was absent whilst they were in the collaborative partner institute. We have characterised these groups of undergraduates as brand supporters rather than brand owners.

\section{Brand Owner (undergraduates permanently resident in the United Kingdom)}

These undergraduates demonstrated a strong emotional and proprietorial attachment to the business school's brand. They noted the importance of the prestige/reputation of the business school brand in their decision to apply to study there are and they believed it would give them a degree of leverage in the job market. These students had a strong loyalty to the business school's corporate brand and its community. Membership of this corporate brand community, it appeared, entailed certain obligations and responsibilities such as meeting certain standards of work and setting an example to the first year undergraduates. Post graduation they wished to be linked to the corporate brand community of the school as well as to the University. In the focus group interview they communicated that the school had a clear corporate brand ethos and identity. The symbolic manifestations of the corporate brand (distinctive 'posh' architecture) and the professional behaviour of MBA students were (to them) clear manifestations of the quality and prestige of the brand. Comparisons were made with the prestige of the University at large whose brand was perceived to be good but of an inferior quality vis a vis the business school's brand.

\section{Management Implications}

\section{Corporate Brand Management Generally}

From our interpretation of the above there to be three, broad, approaches to the management of corporate brands in the institutions examined here 
(Legalisation, Realisation and Actualisation). Taking an historical, and marketing perspective these approaches are analogous to the product, sales and marketing/corporate marketing evolutionary stages that characterises the marketing discipline (Balmer and Greyser 2006). We also go on to make some general observations in terms of the important role of corporate communicators vis a vis corporate brand management in the section that follows.

As a means of assisting those managers having responsibility for the corporate brands of business schools we characterise each of the above modes by a series of questions/explanations. We conclude that approach 1 (a bureaucratic/product emphasis to corporate brand management) is to be avoided; that approach 2 (a diplomatic/communications approach) represents a considerable improvement but should be viewed as an interim stage to 3 . A custodial/brand values approach should be seen as the ideal approach to be followed in managing a corporate brand in the HE sector.

\section{Approach 1 "Legalisation"}

Do you see your obligations to the management of corporate brand identification in legal terms? Is little/no importance accorded to corporate communications/symbolic management? Do you take little/no account of the elements comprising the corporate marketing mix?

If the answer is "yes" to the above then it would appear that your institution has adopted a bureaucratic/product management approach to its corporate brand and is likely to result in low brand identification on the part of students (student regarding their status as being that of brand members: see earlier discussion). Your approach is, essentially, a legalistic one and you should make a strategic move towards 2 and 3 outlined below. 


\section{Approach 2 "Realisation"}

In addition to your legal obligations towards students do you see the management of corporate brand identification primarily in terms of effective corporate communications/symbolic management? Do you marshal only part of the corporate marketing mix?

If the answer is "yes" to the above then it would appear that your institution has adopted a diplomatic/communications approach to its corporate brand and is likely to result in a moderate degree of brand identification on the part of students (students regarding their status as being that of brand supporters: see earlier discussion).

\section{Approach 3 "Actualisation"}

Do you adopt a custodial/brand values approach to the management of corporate brand identification and ensure that there is alignment between brand promise and corporate identity? In addition to your legal obligations towards students and the care taken in terms of corporate communications/symbolic management do you see ownership of the corporate brand as residing with students? Do you marshal all elements of the corporate marketing mix?

If the answer is "yes' to the above then-broadly speaking-a custodial/brand values approach has been adopted by your institution and this is likely to result in a high degree of brand identification on the part of students (students regarding their status as being that of brand owners: see earlier discussion).

\section{Corporate Brand Managers and the Role of Corporate Communicators}

We wish to make several, very general, observations in terms of the important role of corporate communicators vis a vis the management of corporate brand identification within business school contexts. From our research it would appear that for students studying overseas a greater reliance needs to be placed on corporate communications/symbolic management in instilling a 
sense of identification with the business school brand. The importance of the above is of especial importance owing to the spatial void where there is no exposure to an organisational setting. For this reason, identification from the institution (in terms of corporate communications) appears to be an important pre-requisite in terms of identification with the corporate brand on the part of students. Moreover, the absence of effective corporate communications/symbolic management may create an identification vacuum that is likely to be filled by the local service provider. Of course, the notion that communication fosters knowledge and awareness is hardly a new finding but our study confirms the importance of this and of corporate communications in corporate branding contexts. There are, now, many approaches and frameworks that can foster effective corporate communications strategies (Scholes and Clutterbuck 1998; Van Riel 1995).

Exhibit Four draws on the findings and managerial implications from this research in a diagrammatic form that illustrates the relationship between corporate brand identification, status, relationships and management styles and emphasis.

\section{PLEASE TAKE IN EXHIBIT FOUR HERE: THANK YOU.}

\section{Further Research}

The next stage of inquiry will be to empirically test the insights derived from this case study. As such, we will examine issues of student identification with corporate identities/corporate brands in a variety of institutional settings. This next stage of inquiry has the potential to clarify the findings outlined here and will, almost certainly, provide new insights. 
Other possibilities for research could include a longitudinal study which tracks the nature of undergraduate identification throughout their time at a University/Business School. Research which investigates the relative strength of identification among high performing students, as opposed to weaker ones, would also represent a potentially rich strand of inquiry. Other types of corporate brand identification would also merit scrutiny from researchers, for instance:

(a) Departmental/University Identification

(for instance, the Department of Music at York vis a vis the University of York)

(b) College/University Identification

(the collegiate Universities of Cambridge, Durham and Oxford being cases in point. For instance, the relative strength and type of student identification with the brand of constituent Colleges or of University)

(c) College/University Identification in Federated Institutions

(the University of London being a case in point for example identification with Royal Holloway College/the University of London)

(c) The impact of National/Cultural Identification on Universities identification

(The impact of country of origin and generic identity in terms of a stakeholder's identification with a University/Business School brand, for instance, the relative strength of identification towards Australian, British, Chinese, French, Swiss, Swedish and US brands among stakeholders. In addition, the degree to which country of origin is aligned to strength of suitable for certain subject areas including marketing, medicine, meta physics, micro biology, music and so on.)

(d) Strength of identification among holders of Bachelor, and Postgraduate Degrees in different institutions 
(What are the causes for an alumnus primary affinity to shift from one institution to another?)

(e) Differences in culture and their effect on identification (see Souden et al., 2006).

(Extant research by Souiden et al. (2006) has shown that differences of culture can effect corporate brand identification and this line of scholarship could, usefully, be applied to the higher education sector.)

Other possibilities for academic inquiry include the preference (in national, cultural and international contexts) of organisational symbolism as indicators of esteem and prestige. For instance, the prestige that prospective students, employers etc associate with certain symbolic forms such as a heraldry and typeface; the importance attached to University ritual and rites of passage (such as matriculation and graduation ceremonies) and the wearing of academic dress. There was evidence from our study that overseas students accord importance to the presence of such symbolism associated with corporate brand heritage.

In non-Further Education contexts issues of customer identification could be examined in relation to, for instance, customer identification to organisations/organisational alliances and generic (industry-wide) identities and corporate brands. (For instance the degree of affinity to an airline; an airline alliance and airlines generally.) From an employee perspective an investigation into the various types of identification that characterise franchise arrangement are likely to be revelatory. (For instance, an examination of employee identification towards the franchisee and franchisor holders: for instance a company holding a franchising license from a hotel brand such as Hilton). Issues of identification are likely to be germane for other stakeholder groups such as shareholders, suppliers, governments, local 
communities and so on. A further, and potentially rich source of investigation, could be to examine issues of identification from the perspective of faculty members, and would-be-employees.

\section{Conclusion}

In bringing our article to a close it is clear that issues of student corporate brand identification represent a significant but under-researched area of scholarship that merits further explication. The distinguished Harvard academic Professor Joseph Nye (2006) coined the phrase 'soft power' to denote the influence a nation acquires when others are drawn to its culture and ideas. We believe that much the same can be said of overseas students who are drawn to established Business School and Universities, whose courses are increasingly offered by overseas collaborative partner institutions. As this modest theory-building case study on corporate brands and identities has revealed that which is "soft" can also be immensely strong: very much like the Sun in Aesop's fable. This is something that policy advisors within Universities, Business Schools and other Higher Education Institutions, might wish to ponder on as part of their strategic deliberations. 
EXHIBIT ONE THE 6CS OF THE CORPORATE MARKETING

\section{(Balmer's Corporate Marketing Mix)}

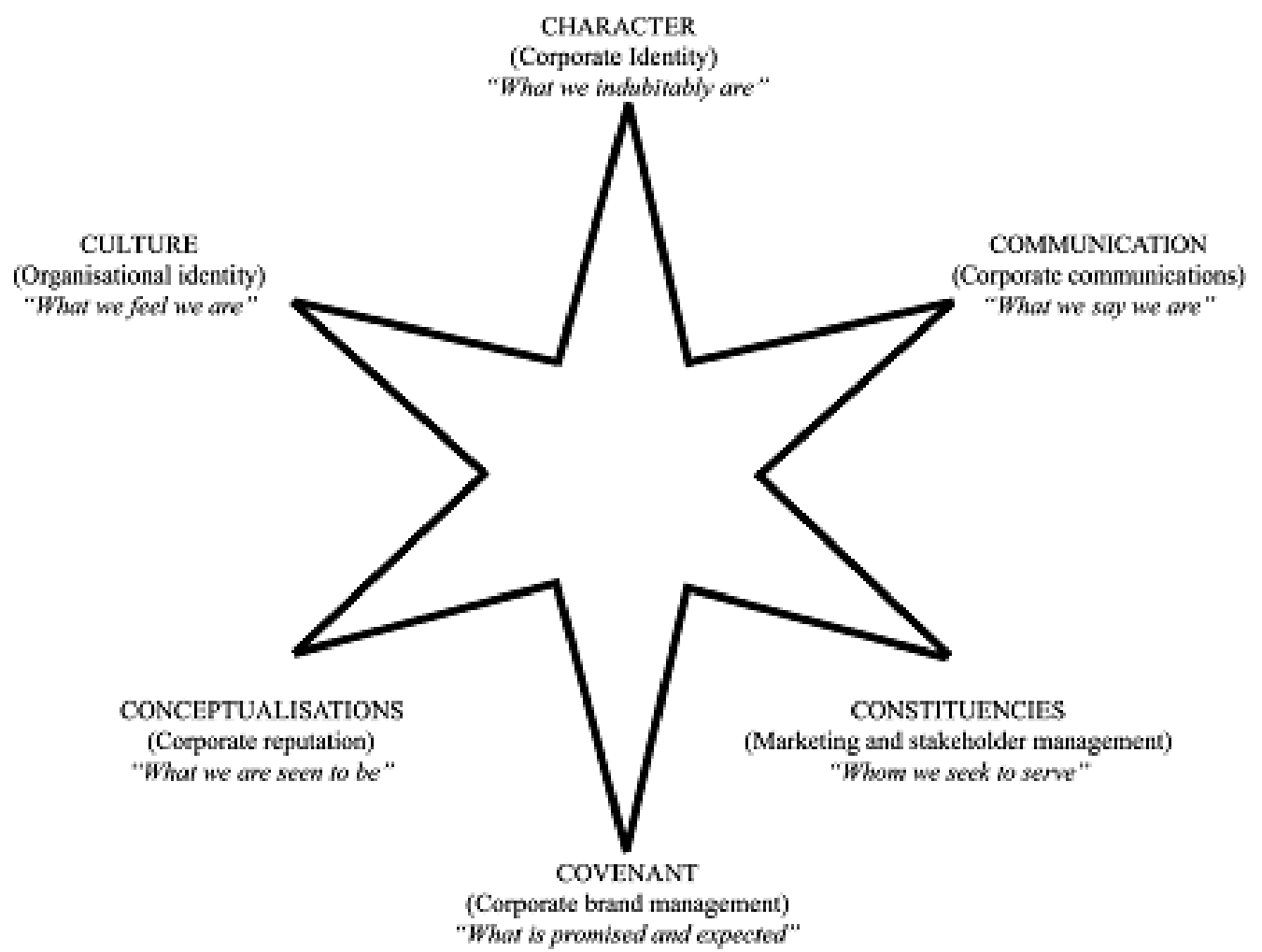

Source: Balmer (2006)

(c) Balmer 


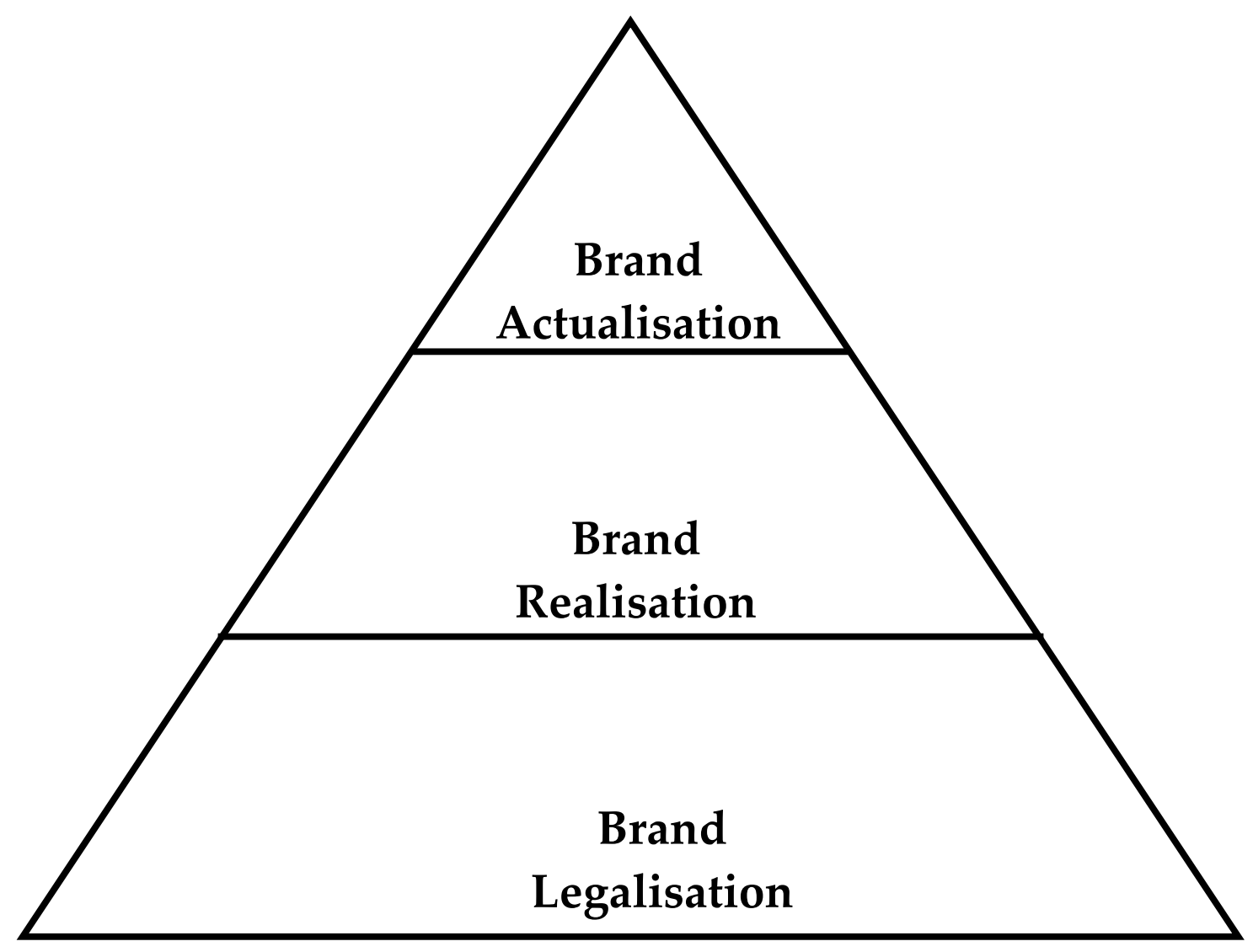

() Balmer and Liao (2007) 
EXHIBIT THREE: A CONCEPTUAL MODEL OF THE RELATIONSHIP BETWEEN STUDENT IDENTIFICATION AND CORPORATE BRAND MANIFESTATIONS

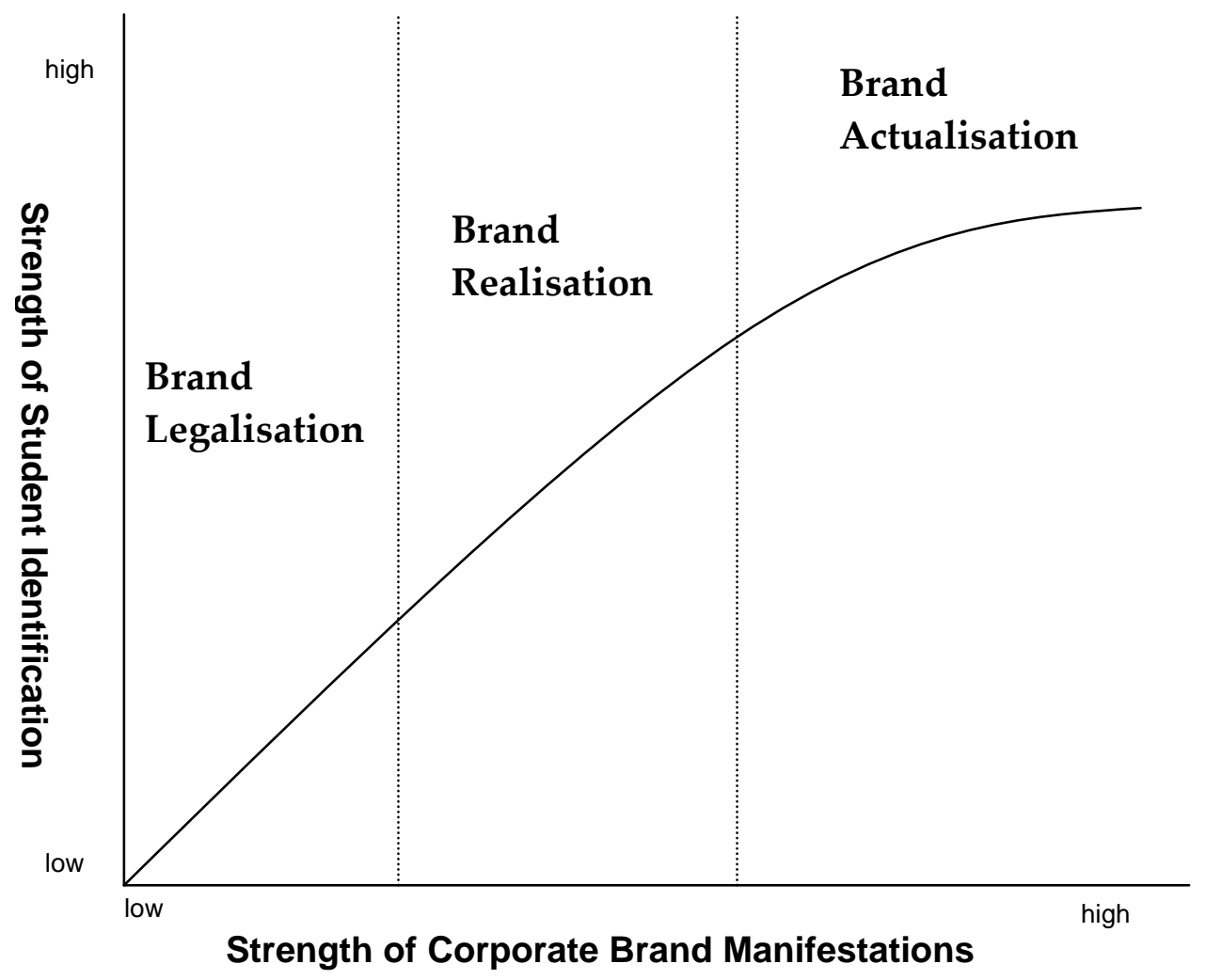

() Balmer and Liao (2007) 


\begin{tabular}{|c|c|c|c|}
\hline CASE STUDY INSIGHTS & $\begin{array}{c}\text { FURTHER RESEARCH } \\
(\text { RESEARCH PROPOSITIONS) }\end{array}$ \\
\hline CORPORATE BRAND & \multicolumn{2}{|c|}{ MANAGEMENT } \\
\hline STATUS & RELATIONSHIP & $\begin{array}{c}\text { MANAGEMENT } \\
\text { STYLE }\end{array}$ & $\begin{array}{c}\text { MANAGEMENT } \\
\text { EMPHASIS }\end{array}$ \\
\hline Member & Legal & Bureaucratic & $\begin{array}{c}\text { Product } \\
\text { Management } \\
\text { (financial } \mathcal{E} \\
\text { functional) }\end{array}$ \\
\hline Supporter & Trusting & Diplomatic & $\begin{array}{c}\text { Communication } \\
\text { Management } \\
\text { (promotional } \mathcal{E} \\
\text { symbolic) }\end{array}$ \\
\hline Owner & Emotional & Custodial & $\begin{array}{c}\text { Brand } \\
\text { Management } \\
\text { (values E promise) }\end{array}$ \\
\hline
\end{tabular}

() Balmer and Liao (2007) 


\section{Notes}

1 The elements of the corporate marketing mix have undergone several reiterations. Balmer's most recent version of the corporate marketing mix. The $6 \mathrm{Cs}$ of corporate marketing encompass: Character, Communication, Constituencies, Covenant, Conceptualisation and Culture.

\section{References and Further Reading}

Aaker, D.A and Joachimsthaler, E. (2000), "The brand relationship spectrum: the key to the brand architecture challenge", California Management Review, Vol. 42, No. 4, pp. 8-23.

Aaker, D.A. (2004), "Leveraging the corporate brand", California Management Review, Vol. 46, No 3, pp. 6-18.

Abratt, R. (1989), "A new approach to the corporate image management process," Journal of Marketing Management, Vol. 5, No. 1, pp. 63-76.

Altbach, P.G. (2004), "Globalisation and the university: Myths and realities in an unequal world", Tertiary Education and Management, Dordrecht: March, Vol. 10, No. 1, pp. 3-16.

Ambiola, T. (2006), "Critical issues in brand management", The Journal of Brand Management, Vol.13, No.4 \&5, pp239-241. (Guest Editorial)

Armstrong, M. J. (2003), "Students as clients: A professional services model for business education", Academy of Management Learning E Education, Vol. 2, No. 4, pp371-374.

Arnauld, E. Price, L. and Zinkham, G. (2002), Consumers, McGraw Hill, New York, NY.

Balmer, J.M.T. (2006), "Comprehending corporate marketing and the corporate marketing mix," working paper series, No.06/08, Bradford University School of Management, UK

Balmer, J.M.T. (2005), "Corporate brand cultures and communities", in Schroeder, J.E. and Salzer-Morling, M. (Eds), Brand Culture, Routledge, London, pp. 34-49. 
Balmer, J.M.T. (2002), “Of identities lost and found," International Studies of Management and Organizations, Vol. 32, No. 3, pp. 10-27.

Balmer, J. M. T. (2001),"The three virtues and seven deadly sins of corporate brand management", Journal of General Management, Vol. 27, No. 1, pp. 1-17.

Balmer, J.M.T. (2001a), "Corporate identity, corporate branding and corporate marketing - seeing through the fog." European Journal of Marketing, Vol. 35, No 3 and 4 , p. 248.

Balmer, J.M.T. (1998), "Corporate identity and the advent of corporate marketing", Journal of Marketing Management, Vol. 14, pp.963-96.

Balmer, J.M.T. (1995), “Corporate branding and connoisseurship,” Journal of General Management, Vol. 21, No 1, pp. 22-46.

Balmer, J.M.T. and Gray, E.R. (2003), “Corporate brands. What are they? What of them?" European Journal of Marketing, Vol. 37, No. 7 \& 8, pp.972-997.

Balmer, J.M.T., Greyser, S.A. and Urde, M. (2006) 'The crown as a corporate brand: insights from monarchies.' Journal of Brand Management, Vol. 14, No. 1 \& 2, pp.137-161.

Balmer, J.M.T. and Greyser, S.A. (2006), “Corporate level marketing: integrating corporate identity, corporate branding, corporate communications, and corporate reputation," Special Edition on Corporate Marketing: European Journal of Marketing, Vol. 40, No. 7 \& 8, pp. 730-741.

Balmer, J.M.T. and Greyser, S.A. (2002), "Managing the multiple identities of the corporation," California Management Review, Vol. 44, No 3, pp. 72-86.

Balmer, J.M.T. and Wilkinson, A.J. (1991), “Building societies: change, strategy and corporate identity", Journal of General Management, Vol. 17, No2, pp.20-33.

Bennell, P. and Pearce, T. (1998), "The internationalisation of higher education: exporting education to developing and transitional Economies", IDS Working Paper, No. 75.

Bhattacharya, C.B. and Sen. S. (2003), "Consumer-company identification: A framework for understanding consumers' relationship with companies", Journal of Marketing, Vol. 67, No 2, p. 76 
Brown, T.J., Dacin, P.A., Pratt, M.G., and Whetten, D.A. (2006), "Identity, intended image, construed image and reputation: An interdisciplinary framework and suggested terminology", Journal of The Academy of Marketing Science, Vol. 34, No. 2, pp. 99-106

Bick, G.M.C., Jacobson and Abratt, R (2003) "The corporate identity management process revisited", Journal of Marketing Management, Vol. 19, pp. 835-855

Bronn, P. Engell, A. and Martinsen, H. (2006), "A reflective approach to uncovering corporate identity", European Journal of Marketing, Vol. 40, No 7 \& 8, pp. 886-901.

Cardador, M.T. and Pratt, M.G. (2006), “Identification management and its bases: bridging management and marketing perspectives through a focus on affiliation dimensions", Journal of The Academy of Marketing Science, Vol. 34, No 2, pp.174-184.

Cornelissen, J.P., Lock, A.R., and Gardender, H. (2001) “ The organisation of external communication disciplines: an integrative framework of dimensions and determinants,' International Journal of Advertising, Vol. 20, pp. 67-88.

Cova, B. and Pace, S. (2006), "Brand community of convenience products: new forms of customer empowerment-the case of 'my Nutella-The Community'", European Journal of Marketing, Vol.40, No. 9 \& 10, pp. 1087-1105.

de Chernatony, L. (2006), From Brand Vision to Brand Evaluation, (second edition), Butterworth-Heinemann, Oxford.

de Chernatony, L. (2002), "Would a brand smell any sweeter by a corporate name?", Corporate Reputation Review, Vol.5, No.2/3, pp.114-135.

de Chernatony, L. and McDonald, M.H.B. (1993), Creating Powerful Brand, Butterworth Heinemann, Oxford.

de Chernatony, L. and Segal-Horn, S. (2002), “The criteria for successful service brands, European Journal of Marketing, Vol.37, No.7/8, pp.1095-1118.

Dobson, I.R. and Holtta, S. (2001), "The internationalisation of university education: Australia and Finland compared", Tertiary Education and Management, Vol. 7, No 3, pp 243-257. 
Dukerich, J.M., Golden, B. R. and Shortell, S. M. (2002), "Beauty is in the eye of the beholder: The impact of organisational identification, identity, and image on the cooperative behaviours of physicians", Administrative Science Quarterly, Vol. 47, No3, p. 507.

Dutton, J.E. Dukerich, J.M. and Harquail, C.V. (1994), “Organizational image and member identification", Administrative Science Quarterly, Vol 39, pp. 239263.

Easterby-Smith, M., Thorpe, R. and Lowe, A (2002), Management Research, Sage, London.

[The] Economist (2006), 12 August, pp.50-51.

Eisenhardt, K.M. (1989), "Building theories from case study research", Academy of Management Review, Vol.14, No. 4, pp. 532-550

Fallshaw, E. M. (2003), “Overseas partnerships - a case study in quality, HERDSA conference proceeding", available at http://surveys.canterbury.ac.nz/herdsa03/pdfsref/Y1052.pdf

Financial Times (2006), 30 January, p.8.

Frerris, W.P. (2002), "Students as junior partners, professors as senior partners, and B-school as the firm: A new model for collegiate business education." Academy of Management Learning E Education, Vol. 1, No. 2, pp185193.

Frerris, W.P. (2003), “Why the partnership model's usefulness far exceeds that of the client model: reply to Armstrong", Academy of Management Learning $\mathcal{E}$ Education, Vol. 2, No. 4, pp. 375-377.

Gatfield, T., Barker, M. and Graham, P. (1999), "Measuring communication impact for university advertising materials", Corporate Communications: An International Journal, Vol. 4, No. 2. p. 73.

Glaser, B. (1978) Theoretical Sensitivity, Sociology Press, Mill Valley, CA.

Gill, J. and Johnson, P. (1991), Research Method for Managers, Paul Chapman Publishing Limited, London.

Goodman, M.B., (2001) "Current trends in corporate communication", Corporate Communications: An International Journal, Vol. 6, No. 2, pp. 69-74. 
Gray, B., Fam, K. S. and Llanes, V.A. (2003), "Branding universities in Asian markets", The Journal of Product and Brand Management, Vol.1 2, No. 2 \& 3, p.108

Gummesson, E. (2005), "Qualitative research in marketing. Road-map for a wilderness of complexity and unpredictability", European Journal of Marketing, Vol. 39, No. 3 \& 4, pp. 309-327.

Gummesson, E. (1991), Qualitative Methods in Management Research, Sage, London. pp. 73-134

Gylling, C. and Lindberg-Repor, K. (2006), "Investigating the links between a corporate brand and a customer brand", The Journal of Brand Management, Vol.13, No.4\&5, pp.257-267.

Hatch, M. and Schultz, M.J. (2001), "Are the strategic stars aligned for your corporate brand?" Harvard Business Review, Vol. 79, No. 2, February.

Holly, F. and Stanworth J., (2002), (Ed) Franchising, An International Perspective, Routledge, London

Kapferer, J-N. (2002) "Corporate brands and organizational identity", In Moingeon, B. and Soenen, G.(eds) Corporate and Organizational Identity, Routledge, London.

Karaosmanoglu, E. and Melewar, T.C. (2006) "Corporate communications, identity and image: a research agenda," Journal of Brand Management, Vol 14, No.1 \& 2, pp. 196-206.

Keller, K.L. and Lehmann, D.R. (2005), "Brands and branding: research findings and future priorities", Marketing Research Institute Special Report, pp.05-200.

King, S. (1991), "Brand building in the 1990s", Journal of Marketing Management, Vol. 7, pp.3-13.

Knox, S. and Bickerton, D. (2003) "The six conventions of corporate branding", European Journal of Marketing, Vol. 37, No. 7 \& 8, pp. 998-1016.

Kotler, P. and Fox, K.F.A. (1995), Strategic Marketing for Educational Institutions, $2^{\text {nd }}$ edition, Prentice Hall, Englewood Cliffs. 
Lloyd, A. and Wiser, M. (2006), “Assuring quality in an overseas collaborative project: A case study", available at, http://www.blweb.it/esoe/tqmhe1/13.pdf

Mael, F. and Ashforth, B.E. (1992), “Alumni and their alma mater: A partial test of the reformulated model of organizational identification", Journal of Organizational Behavior, Vol. 13, No 2, pp.103-123.

Margulies, W. (1977), "Make the most of your corporate image," Harvard Business Review, (July-August), pp. 66-77.

Mazzarol, T. (1998), "Critical success factors for international education marketing", International Journal of Educational Management, Vol. 12, No. 4. pp163-75

Mazzarol, T. and Soutar, G.N, (1999), "Sustainable competitive advantage for educational institutions", International Journal of Educational Management, Vol. 13, No. 6. pp. 287-300.

McAlexander, J.H, Schouten, J.W and Keonig, H.F. (2002), “Building brand community", Journal of Marketing, Vol. 66, pp. 38-54.

Melewar, T.C. and Karaosmanoglu, E. (2006), "Seven dimensions of corporate identity: a categorisation from the practitioners' perspectives", European Journal of Marketing, Vol. 40, No. 7 \& 8, pp. 846-885.

Melewar, T.C. , Saunders, J. and Balmer, J.M.T. (2003), “ Cause, effect and benefits of a standardised corporate visual identity system of UK companies operating in Malaysia", European Journal of Marketing, Vol. 35, No 3 \& 4, pp. 414-427.

Melewar, T.C. and Jenkins, E. (2002), "Defining the corporate identity construct", Corporate Reputation Review, Vol. 5, No1, pp. 76-91

Melewar, T.C. (2001) "Measuring visual identity: a multi-construct study", Corporate Communications, Vol. 6, No 1, p 36.

Muzellec, L. and Lambkin, M. (2006), “Corporate rebranding: destroying, transferring or creating brand equity", European Journal of Marketing, Vol.40, No.7\&8, pp803-824.

Napoles, V. (1988), Corporate Identity Design, John Wiley and Son, New York. 
Normann, R. (1970), "A personal quest for methodology", Scandinavian Institutes for Administrative Research, Stockholm, Vol. 53, pp. 6-26.

Nye, J. (2006), in Financial Times, September 30/October 1, p. 6.

Olins, W. (1978), The Corporate Personality. An Inquiry into the Nature of Corporate Identity, Design Council, London.

Pilditch, J. (1971), Communication by Design: A Study in Corporate Identity, McGraw Hill, Maidenhead.

Pratt, M.G. (1998), “To Be or Not to Be?” Central Questions in Organizational Identification", In D. Whetten and P. Godfrey (1998) (Eds) Identity in Organizations: Developing Theory Through Conversations, Thousand Oaks, CA: Sage, pp. 171-207.

Scholes, E. and Clutterbuck, D. (1988) “Communicating with stakeholders: an integrated approach,' Long Range Planning, Vol. 31, pp. 227-338.

Schouten, J.W. and McAlexander, J.H. (1995), "Subcultures of consumption: an ethnography of the new bikers", Journal of Consumer Research, Vol. 22, pp.43-61.

Schroeder, J. E. (2005), Visual Consumption, Routledge, London

Schults, M. and de Chernatony, L. (2002), “Introduction- the challenges of corporate branding", Corporate Reputation Review, Vol.5, No.2 \&3, pp.105-112.

Siu, N.Y.M. and Wilson, R.M.S. (1998), "Modelling market orientation: An application in the education sector", Journal of Marketing Management, Vol.14, 293-323.

Solomon, M.R. (2003), Conquering Consumerspace, Marketing Strategies for a Branded World, Amacom, New York, NY.

Selame, E. and Selame, J. (1975), The Company Image, New York, John Wiley.

Simoes, C., Dibb, S., and Fisk, R. P. (2005), “Managing corporate identity: an internal perspective", Journal of the Academy of Marketing Science, Vol. 33, No 2, pp. $153-168$ 
Souiden, N, Kassim, N.M. and Hong, H-J (2006) "The effect of corporate branding dimensions on consumers' product evaluation,' European Journal of Marketing, Vol. 40, No. 7 \& 8, pp.825-845.

Stake, R.E. (1987), "The case study method of social enquiry", Education Researcher, Vol. 7, No. 2, pp.5-8.

Stuart, H. (1999), “Towards a definitive model of the corporate identity management process", Special Edition on Corporate Identity: Corporate Communications: An International Journal, Vol. 4, No 4, pp. 200-207.

Teichler, U. (1999), "Internationalisation as a challenge for higher education in Europe", Tertiary Education and Management, Vol. 5, No. 1, pp. 5-19.

Universities UK (2006) Universities boost value of 'UK plc' says report, 11 May 2006, available at http://www.universitiesuk.ac.uk/mediareleases/show.asp?MR=454

Vallaster, C. and de Chernatony, L. (2006), "Internal brand building and structuration: the role of leadership", European Journal of Marketing, Vol. 40, No. $7 \& 8$, pp. 761-784.

Van den Bosch, A.L.M., Elving, W.J.L. and De Jong, M.D.T. (2006) “The impact of organisational characteristics on corporate visual identity,' European Journal of Marketing, Vol. 40. No. 7 \& 8, pp.870-885.

Van Maanen, J. (1988), Tales of the Field: On writing ethnography, University of Chicago Press, Chicago.

Van Riel, C.B.M. (1995) Principles of Corporate Communications, Prentice Hall, London.

Van Riel, C.B.M. and Balmer, J.M.T. (1997), "Corporate identity: the concept, its measurement and management", European Journal of Marketing, Vol 31, No 5 and 6, p. 340.

Uggla, H. (2006), “The corporate brand association base: a conceptual model for the creation of inclusive brand architecture", European Journal of Marketing, Vol.40, No.7\&8, pp785-802. 
Varey, R. and White, J. (2000) "The corporate communications systems of managing,' Corporate Communications: An International Journal, Vol. 5, No. 1 pp. 5-11.

Westcott Alessandri, S. (2001) "Modelling corporate identity: a concept explication and theoretical explanation," Corporate Communications: An International Journal, Vol. 6, No. 4, pp. 173-182.

Worthington, S. and Horne, S. (1995), "Alumni affinity credit cards: making the relationship work", The International Journal of Bank Marketing, Vol.13, No. 5, pp.24-31.

Yamauchi, K. (2001) "Corporate communications: a powerful tool for stating corporate missions," Corporate Communications: An International Journal, Vol. 6. No. 3, pp. 131-136.

Yin, R.K. (1984), Case Study Research: Design and Methods, Sage, Newbury Park, CA.

Yu, K. (1996), "The internationalisation of higher education", Organisation for Economic Cooperation and Development. The OECD Observer, Oct/Nov, No. 202, pp. 34-37. 